\title{
PERCEIVED QUALITY AND CORPORATE IMAGE IN MOBILE SERVICES: THE ROLE OF TECHNICAL AND FUNCTIONAL QUALITY
}

Vesna Babic-Hodovic, Maja Arslanagic-Kalajdzic, Amina Imsirpasic

\section{Abstract}

The purpose of this study is to assess the technical (output) and functional (process) quality of mobile services, as well as the role of corporate image as a mediator between technical/functional quality perceptions and overall quality assessment of mobile services. Grönroos's service quality model is used as the conceptual base of the study. Technical quality was operationalized through two sub-dimensions: baseline network quality and augmented technical quality. The SERVPERF framework was used in the operationalization of the functional quality. A quantitative survey was conducted with $(n=414)$ customers of the telecommunication operator in $B \& H$. The results suggest that corporate image mediates the effects of (1) two functional quality dimensions (tangibles and assurance) and (2) both technical quality dimensions on the overall service quality assessment. The core technical quality dimension (network) is also directly related to overall service quality perception. A discussion of the results and their implications for theory and practice is then presented.

Keywords: mobile services, technical service quality, SERVPERF, perceived image

JEL classification: $M 31, M 80$

\section{INTRODUCTION}

Due to its specific nature, the concept of quality is of extremely high importance in services, both for service providers and for service customers. Perceived service quality is the result of a customer's evaluation of the specific superiority or deficiency in a service (Lovelock and Wirtz 2011; Zeithaml 1988). It may also be viewed as a customer attitude resulting from a comparison between customers' expectations and experiences with service performance (Angell, Heffernan and Megicks 2008; Kahn, Strong and Wang 2002; Parasuraman, Zeithaml and Berry 1988). Perceived quality is hence a subjective category and cannot be compared with objective quality, which involves the objective assessment of products, objects, or standardized processes. It should be indicated that it is much more difficult for customers to assess service
Vesna Babic-Hodovic, PhD

University of Sarajevo

School of Economics and Business

E-mail: vesna.babic-hodovic@efsa.unsa.ba

Maja Arslanagic-Kalajdzic, $\mathrm{PhD}$

University of Sarajevo

School of Economics and Business

E-mail: maja.arslanagic@efsa.unsa.ba

Amina Imsirpasic, MSC

BH Telecom/Development department

E-mail: amina.imsirpasic@bhtelecom.ba 
quality than to evaluate product quality (Hoffman and Bateson 2010), especially when it comes to external services (Marković 2006). The quality assessment of services is usually done based on service outcome and service process (Grönroos 1984; Lovelock and Wirtz 2011; Mittal 2016).

A customer's evaluation of service quality relies profoundly upon the degree of contact and the presence of the customer when the service is provided. On the one hand, for services that assume intense customer participation and (typically) interaction with first-line employees, service quality is assessed in the process of providing services (Brady and Cronin 2001; Firdaus 2006; Lehtinen and Lehtinen 1982). For example, Sandada and Matibri (2016) used a modified service quality model for airline services and evaluated only dimensions directly related to the service process (tangible elements of the trip and employee attitudes). On the other hand, low-contact services assume a low level of interaction and customers have a relatively passive role (Bowen and Youngdahl 1998; Verma and Young 2000) since they are the recipients of services developed through and based on technical performance and successful service activation. In these cases, quality perception is more output-oriented.

Grönroos's service quality model (1984) includes three main concepts that explain the process of overall service quality: technical (output) quality, functional (process) quality and corporate image. Accounting for both technical and functional quality, both contact-intensive and low-contact services are encompassed and can be evaluated. While functional quality has been conceptualized and operationalized in great detail in previous literature (starting from SERVQUAL; Parasuraman, Zeithaml and Berry 1988), it is very difficult to consistently conceptualize technical quality in different service industries. Thus, technical quality has not yet been conceptualized in a form that could be generally applied across industries (Mohsin and Lockyer 2010).

The focus of this study is on the mobile services industry, which is one of the fastest growing industries in recent decades. Furthermore, this industry combines evaluation of technical (output) quality, which is primarily assessed as it is in the core of mobile services, and functional quality (process) quality, assessed through all points of contact with the provider (i.e. customer support). This makes mobile services a good prototype to test perceptions of service quality (e.g. Nimako et al. 2012; Lai, Griffin and Babin 2009; Liang, Ma and Qi 2013).

The intended contribution of this research is twofold. First, in a similar manner as Kang and James (2004), we apply Grönroos's model to the mobile service industry, but now focusing on a developing country setting. Our application of the model is unique since it (1) focuses on the customer perceptions for all elements in the model and (2) allows all dimensions of technical and functional service quality to be related to the outcomes in the model in order to better understand the differential effects of different dimensions.

Second, we propose and empirically test a twodimensional measure of technical service quality in mobile services. Previous studies analyzed technical quality (e.g. Nimako et al. 2012; Kang 2006; Kang and James 2004) as an overall (uni-dimensional) construct. Since the mobile services industry has advanced significantly in recent years, its core technical service should be assessed in a more in-depth approach. We thus aim to gain a better understanding into the technical (output) quality of mobile services.

The rest of the paper is organized as follows. We first make a detailed overview of corporate image and service quality concepts in order to develop our conceptual model and hypotheses. We then proceed with the methodology outline, the results of the study and a discussion of the implications for further research, and conclusions.

\section{LITERATURE REVIEW AND CONCEPTUALIZATION}

For the purposes of our research we adapt Grönroos's (1984) perceived service quality framework (see Figure 1). We first review the existing literature, and then develop and empirically test the links between perceived functional and technical quality, perceived corporate image and overall quality assessment.

\subsection{Perceived corporate image}

Researchers have used different levels of analysis and conceptualization when discussing the concept of corporate image. Keller (1993) defines company-level image as perception of an organization reflected in the associations held in customers' memory, while Bitner (1991), Grönroos (1984) and Gummesson and Grönroos (1988) have insisted on the importance of corporate image in the overall evaluation of the service and the company. Other literature streams advocate the opposite view, that corporate image may be created even without personal experience with the service (e.g. Bravo, Montaner and Pina 2009; Hawabhay, Abratt and Peters 2009; Huang et al. 2014; Lin and Lu 2010). 
Figure 1: Conceptual framework

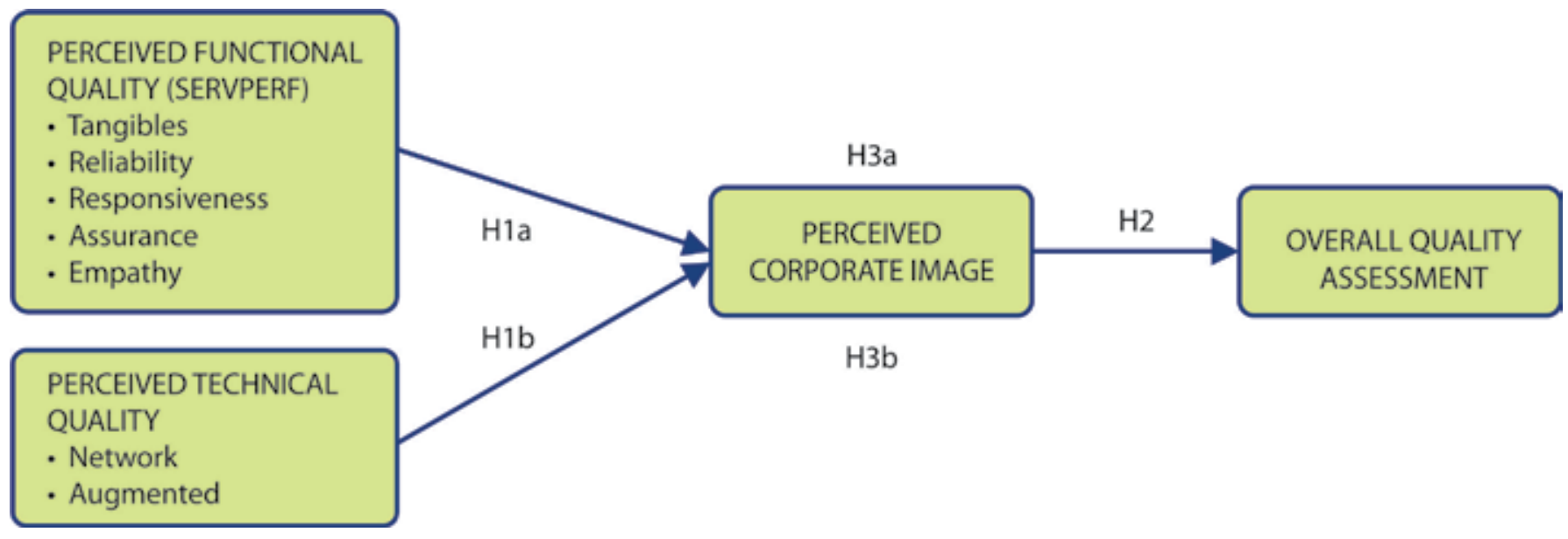

Many authors (e.g. Hatch and Schultz 1997; 2003; Fombrun 1996; Kazoleas et al. 2001) understand corporate image as the "overall impression" created in a customer's mind based on previous experiences with the organization or accumulated customer experience (Weiwei, 2007). This comprises, in short, customers' feelings and attitudes, transformed into a positive/ negative meaning which customers connect with the name of the organization. Previous research connects corporate image with the company, its meaning, and promises to stakeholders. In services, image is also related with consistency in service provision, interaction and delivered quality. Barich and Kotler (1991) explain corporate image as the overall impression that a person holds about a firm; Aaker (1996) as "the net result of all the experiences, impressions, beliefs, feelings and knowledge that people have about a company" (p. 113), while Nandan (2005) and Brown et al. (2006) support these explanations by defining corporate image simply as everything that individuals know or believe about an organization. In the study, corporate image is conceptualized as a perception of a firm's presentation in a customer's mind.

Andreassen and Lindestad (1998) suggest that a service company's image has a role of a filter in the perception of quality. Being able to recall corporate image in their mind, customers simplify the whole decision-making process when considering alternative services and service providers, which makes the evaluation of services easier. This explanation is consistent with Grönroos's (1984) proposal about the role of corporate image in the evaluation of technical and functional quality dimensions in the total service quality perceived by customers. Practically, this means that if a service firm has a positive image in public, the negative effects of possible failure do not immediately translate into in a form of dissatisfaction (or bad evaluation), but are instead buffered by customers' favorable image of the organization. Similarly, companies with a negative image face problems no matter how excellent their service interactions are, they may not have a significant impact on customer perceptions of quality or satisfaction. Namely, they are being filtered through the prism of a poor corporate image.

\subsection{Overview of service quality models}

Research in the field of service quality has increased dramatically over the last three decades (selected examples: Angell, Heffernan and Megicks 2008; Ban and Ramsaran, 2017; Babakus and Boller 1992; Brochado 2009; Finn and Lamb 1991; Firdaus 2006; Murgulets et al. 2002; Parasuraman et al. 1985, 1988, 1991, 1994; Shekarchizadeh, Rasli and Hon-Tat 2011; Zeithaml et al. 1990, 1993). Service quality is usually explained through the disconfirmation theory (Brown and Kirmani 1999; Jiang, Klein and Crampton 2000; Oliver 1997; Oliver 1980; Spreng and Page 2003; Spreng and Mackoy 1996): Service quality determines the extent to which the services provided have met customers' expectations. Providing high-quality services means the continuous confirmation of customers' expectations. The most prominent disconfirmation-based model is the SERVQUAL model (Service Quality Model; Parasuraman, Zeithaml and Berry 1988) categorized as the "American" perspective of the conceptualization of service quality measurement. Further, a SERVPERF model version has been extracted from the SERVQUAL model (Cronin and Taylor 1992), assuming only customers' perceptions when evaluating perceived service quality. This model demonstrated superiority to SERVQUAL in some aspects, and it has been used when focusing on customer perceptions of quality 
outcomes (Dlačić et al. 2014; Brady, Cronin and Brand 2002; Cronin and Taylor 1992).

Grönroos (1984), who belongs to the so-called "Nordic" perspective, also defines his service quality model based on the disconfirmation paradigm. He further defines service quality as the unity of service process and service output quality evaluation (Grönroos 1982, 1984). In contrary, both the SERVQUAL and SERVPERF models are dominantly focused on functional (process) quality measurement (Richard and Allaway 1993). Although Parasuraman et al (1985), under the influence of European scholars, accept ideas about the importance of technical quality (service output quality), their model still reflects the functional aspect only (Kang and James 2004). In this study, we also use SERVPERF for conceptualization of the functional quality dimension, as well as perceptions for all other constructs from the original Grönroos model (1984).

Service quality models were applied and tested in many industries, including the mobile and telecommunication service industry (e.g. Leisen and Vance 2001; Negi, 2009; Van der Wal, Pampalis and Bond 2002; Wang and Lo 2002; Ward and Mullee 1997). SERVQUAL was specifically used for fixed line telephone services (Leisen and Vance 2001), fixed line and mobile services (Johnson and Sirikit 2002), and mobile services (Van der Wal, Pampalis and Bond 2002).When it comes to mobile services, Wang and Lo (2002) found that network quality and empathy are the two most important factors of service quality perception among Chinese users of mobile services, while Ranaweera and Neely (2003) used SERVPERF for a fixed line telephone services study, but with slight modification; they included prices and indifference, which are confirmed in having moderate effects on service quality perception. Kim, Park and Jeong (2004) found that service quality had a strong impact on customer satisfaction and that call quality was the most important factor affecting service quality perception. Mobile service providers were studied in different cultural contexts e.g. Brazil (Souki and Filho 2008), China (Lai, Griffin and Babin 2009), Greece (Sigala 2006), India (Sukumar 2007), Malaysia (Arokiasamy and Abdullah 2013), Pakistan (Khan 2010), South Africa (Barhnhoorn 2006), Thailand (Johnson and Sirikit 2002) and Turkey (Özer and Aydin 2005), but no study has yet examined it in the context of a developing European country.

\subsection{Functional and technical service quality}

There is a consensus among authors about the multidimensionality of service quality (Berry 1986;
Grönroos 1982, 1990; Parasuraman et al. 1985), but not about the exact nature and content of these dimensions (Brady and Cronin 2001). Lehtinen and Lehtinen (1982) discuss physical quality (which is acceptable in cases when the results of the service process are tangible, such as in architectural or restaurant services), interactive quality and corporate image in a similar manner as Grönroos (1982). Later, Lehtinen (1983) explained service quality in terms of process quality and output quality, although without discussion of corporate image. Swartz and Brown (1989) synthesized the discussions above into "what" (issues evaluated after service is delivered) and "how" (issues evaluated during the process of service delivering). Rust and Oliver (1994) stated that customers evaluate a service encounter based on the mutual interaction between customers and employees (functional quality), the service environment (physical quality) and the outcome (technical quality), while in understanding of others (i.e. SERVQUAL model), functional and physical quality are usually observed jointly, as a process element of the quality.

Functional quality could be explicated as a perception of the way in which a service was provided; it defines a customer's perception of interaction that takes place during the service provision process and relates to the satisfaction that the service recipient feels toward the process or experience of receiving the service (Arora and Stoner, 1996). On the other hand, technical quality reflects the result of the service action, service output or what the customer received after the service encounter.

A very important issue for understanding this conceptualization of service quality is customers' ability to assess the technical quality types of services. Service customers are frequently unable to evaluate service output quality, even after the service encounter, since they do not have suitable expertise/knowledge or experience (Grönroos 1984; Lehtinen and Lehtinen 1982; Opoku et al. 2009; Babic-Hodovic 2010). As a result, functional quality often becomes a compensation for the technical quality evaluation and customers often over-stress this dimension (Grönroos 1990; Richard and Allaway 1993). This is especially the case in professional and highly sophisticated services (e.g. medical, consulting or educational ones). In the case of telecommunication and/or mobile services customers usually have fewer problems in evaluating technical quality. Even without knowing technical details, they evaluate the results of using the service (e.g. successful connection, disturbances during usage).

Researchers also agree about the fact that technical quality significantly affects customer perceptions of overall service quality (Carman, 2000, Grönroos 1982, 
1984, 1990, Rust and Oliver 1994). Grönroos (1984, p. 38) defines this factor as "what remains to the customer when the service process has been completed". Solomon et al. (1985) express technical output as an "actual" service and consider it the determinant in assessing the quality of a service encounter, while Rust and Oliver (1994) explicate service output as a "service product" and believe it to be a relevant characteristic that customers assess after the service encounter.

Schneider and Bowen (1995) demarcated technical quality as the essence of the service, defining it as the measure of the "core service". They accept the importance of service processes and interaction, but also point out that the process (e.g. delightful environment or friendly contact staff) cannot eliminate dissatisfaction due to the poor core service (e.g. lousy food, poor financial advice, or inadequately maintained mobile service). Consequently, they insist that core service could become prevalent compared to other elements related to service delivery. The nature and quality of this core service is what influences customer perception of quality the most. This explanation is based on the assumption that the characteristics of services being offered are equally or even more important as the way in which the service is provided (Rust and Oliver 1994). In the context of mobile services, researchers have discussed the high impact of the results of using mobile services, which can cause customer dissatisfaction even in the cases of prestige mobile operators (Blery et al 2009; Khan 2010; Seth and Gupta 2008;Tiwari and Verma 2008).

Despite acceptance of the idea that technical quality significantly affects customer perceptions of service quality (Grönroos, 1982, 1990; Rust and Oliver, 1994) marketing scholars have yet to identify the attributes of this dimension; the problems are related specifically to the possibility of the generalization of those attributes. Studying the mobile service category, the research is aimed at identifying the possibility for measuring the technical and functional dimensions of mobile service quality, and at determining the levels of impact from each on overall service quality, with corporate image as the filter between these relations.

Research on technical (output) service quality has taken different approaches. A study conducted in the USA measures technical quality dimensions through network coverage, voice service quality and un-established calls, price plans and the content of individual services (Lim, 2005), while a study conducted for mobile services in South Korea took into account only the "voice" service for defining technical quality (Kang and James, 2004). Other research conducted in Hong Kong showed that the most important factors for customers include network coverage and transmission quality, since they are a pre-requisite for using other services (Woo and Fock, 1999).

The starting point for the conceptualization of technical quality in this research was an understanding of the notion of mobile services in the telecom sector. It implies the core services, the use of which satisfy the customer's need or desire for communication. It is common that the following four types of core services: voice, SMS, GPRS, and MMS, could be found with each mobile provider, with other services based on these core services. Customers will base their evaluation of the technical quality on the assessment of core services. The technical dimension of service quality in the case of telecom operators output (result) is a result of the interaction for the customer who uses phone calls, sends an SMS, etc. Customers can assess if the call was successfully completed, interrupted without their will, if noises or echo are present during the conversation, or whether an SMS was successfully sent; this gives them the possibility to evaluate technical quality without problems.

It is also very important to determine the key factors of the technical dimension of mobile network service quality for customers. In accordance with technical recommendations in the field of telecom services, quality of service (QoS) in technical terms is defined as the "overall influence of service performance that determines the degree of a customer's satisfaction with the provided service" (E.800, 1994). The focus here is on the output quality, which has several stages (GSM Association, PRD IR.41, 2002): (1) network access, network indication on the phone display is a signal to the customer that he can use the operator's services; (2) service access, if the customer wants to use some of the available services, the operator should allow the fastest service access possible; (3) service integrity, describes the quality of service during the use of service (e.g. voice transfer without noise, echo, data transmitted from point $A$ to point $B$ should be identical, without data loss during the transfer); (4) service retainability, the capacity to retain the service. Service retainability describes service termination due to the customer's will (the customer has by his own will finished using the service, or the use of service was terminated for another reason beyond the customer's will - loss of signal, unsuccessful 'handover'). In order to specify various QoS parameters (customer aspect) and NP parameters (network aspect), the following nine generic parameters can be used (ETR 003 ed.2, 1994): (1) speed of service access, (2) accuracy in access, (3) access certainty, (4) speed of information transmission, (5) accuracy of information transmission, (6) certainty of information transmission, (7) speed of termination of service use, (8) accuracy of termination, 
(9) certainty of termination. They were taken as a starting point for the conceptualization of technical service quality.

The technical and functional service quality dimensions described above are used as important cues for the evaluation and perception of corporate image (Bravo et al. 2009). Since corporate image is defined as perception of a firm's presentation in the customer's mind, additional perceptions customers gain through the assessment of technical (Schneider and Bowen 1995) and functional (Cronin and Taylor, 1992) quality will be directly related to the formulation of perceived image (LeBlanc and Nguyen, 1996; Nguyen and LeBlanc 2001). Furthermore, as recommended by Grönroos (1984) and further evaluated by Nimako et al. (2012), Kang and James (2004) perceived that corporate image will impact the overall quality assessment and will serve as a filter and carrier (Andreassen and Lindestad, 1998) of the effect of technical and functional quality on the overall quality assessment. Based on the outlined theoretical framework and the review above (see Figure 1), we hypothesize:

H1: Perceived mobile service provider's corporate image is positively influenced by perceived (a) technical and (b) functional service quality.

H2: Perceived mobile service provider's corporate image positively impacts overall quality assessment of mobile services.

H3: Perceived mobile service provider's corporate image mediates the effect of (a) technical and (b) functional service quality on overall quality assessment of mobile services.

\section{METHODOLOGY}

In order to operationalize key concepts in the study, literature was consulted for the existing measures on functional quality (SERVPERF, Cronin and Taylor 1994), and corporate image (Kim and Hyun 2011). When it comes to technical quality, the selection of indicators was done based on qualitative research and a pre-test. First, a pool of 21 items for technical quality criteria was generated pertaining to: (1) ability of the customer to register and evaluate the quality of the service, (2) importance of the indicator for the customer. A set of 16 in-depth interviews were then conducted with customers who evaluated the face validity of the items and assessed whether they could provide answers and perceive/observe all phases of technical quality assessments. During the interviews, respondents confirmed the concept of three phases of service use: access to the service, service integrity and retainability (all given in the technical recommendations of the GSM association PRD IR.41).

Customers then narrowed down the pool to the set of 11 items that relate to the services of talking, SMS, MMS, and data transfer. Overall quality was measured based on one item - overall impression and assessment of the quality by the customer. Finally, we conducted a pre-test with 38 customers, asking them to rate the items on a 1-5 Likert scale to assess the properties of the items. All the items showed good reliability, so we proceeded with the main study.

To empirically validate the proposed theoretical framework, a quantitative study was conducted in a developing market, selecting customers from one telecommunications provider. The telecommunications industry is undergoing oligopolistic competition. There are only a few telecommunication service providers, but they are in very extreme competition and are trying to build a good image in the industry relative to their competitors. Therefore, the main focus of these corporations is to retain their existing customers after attracting new customers, and to accomplish this customer perception of service quality and their attitudes regarding corporate reputation are extremely important.

The sample was derived from the overall database of customers of the selected telecommunication company, based on the following set of criteria: (1) they are registered for using the basic range of mobile services (voice services) and data mobile services (SMS, access to mobile Internet through GPRS, MMS), (2) they contacted the Customer Care Center in the previous six months before the start of research. The telecom sector belongs to service sectors where service delivery is mostly based on a technological equipment, and it is a facility/equipment based industry where the customer in the process of using services mostly has no contact with the operator's staff except in the case of a problem or complaint. For measuring the functional quality dimension it was necessary for customers to have some experience being in contact with the operator's staff; and hence (3) they had provided the operator with their e-mail. A total of 800 customer contacts were then randomly drawn from the database of the provider. An e-mail with the electronic version of the questionnaire was sent to customers, assuring them of anonymity. After a several reminders, a total of 414 usable responses (52\% response rate) was received and used for subsequent analysis. When it comes to descriptive statistics, $65 \%$ of the respondents were female, $44 \%$ falling into the age group $25-35$, and $44 \%$ with monthly incomes higher than the national 
average. When it comes to relationship length, most respondents (54\%) were long-term customers of the given telecommunications operator - between 10 and 15 years.

\section{RESULTS}

We first conducted an exploratory factor analysis (Principal axis factoring method, Varimax rotation) in order to examine the underlying structure of 11 selected technical quality items. A factor analysis solution converged in two dimensions, explaining $60 \%$ of variance (Average variance extracted $=59.93$ ) with factor loadings ranging from 0.61 to 0.78 for all of the items. The first extracted factor encompasses the following six items: network signal, success in establishing a call, no noise and echo during the call, no unplanned interruptions of the call, success in sending SMSs, and confidence in quick SMS delivery. The second extracted factor encompasses the following five items: success in establishing mobile Internet connection, maximum speed of data transfer, no unplanned interruptions in mobile Internet connection, success in sending MMSs and ability to open the received MMS. By examining the substance of the two extracted factors, we labeled the first factor as the network (in terms of core network/technical services) dimension and the second factor as the augmented (in terms of additional network/technical services) dimension. Both dimensions have Cronbach's Alpha scores of 0.89 .

We then proceeded to conduct a confirmatory factor analysis (CFA) in Lisrel 8.71, to test for validity and reliability of the selected measures (see Table 1). It could be observed that all indicators are within the given thresholds (Anderson and Gerbing 1988, 1991), with factor loadings ranging from 0.56 to 0.92 , composite reliability being higher than 0.80 in all cases, and the average variance extracted higher than 0.50 (Bagozzi and Yi 2012). Further, discriminant validity was assessed by assessing correlation coefficients and their relation to the average variance extracted (Mackenzie, Podsakoff, and Podsakoff 2011). The measurement model shows a good fit $\left(\mathrm{df}=637 ; \chi^{2}=\right.$ $1,713.53 \chi^{2} / \mathrm{df}=2.69 ; \mathrm{RMSEA}=0.06 ; \mathrm{NNFI}=0.98 ; \mathrm{CFI}=$ 0.98; SRMR $=0.05$ ).

The hypothesis test was conducted using a covariance-based structural equation modeling (SEM) approach, again in LISREL 8.71 (see Table 2).

The hypothesis test shows that the hypothesis related to functional quality $(\mathrm{H} 1 \mathrm{a})$ is only partially confirmed, with tangibles $(\beta=0.478, p<0.001)$ and assurance $(\beta=0.247, p<0.05$ ) being the only two significant SERVPERF dimensions. On the other hand, both dimensions of the proposed technical quality dimensions, network $(\beta=0.272, p<0.001)$ and augmented $(\beta=0.102, p<0.05)$ are significant. This fully confirms the second part of the hypothesis $(\mathrm{H} 1 \mathrm{~b})$. When it comes to the second hypothesis, it is confirmed, since corporate image positively and strongly impacts overall quality $(\beta=0.636, p<0.001)$. Finally, our third hypothesis assumed a mediating role of corporate image for the effect of functional and technical quality on overall quality evaluations. We can see that for functional quality $(\mathrm{H} 3 \mathrm{a})$ is partially confirmed, since corporate image does fully mediate the effect of tangibles and assurance, while for technical quality $(\mathrm{H} 3 \mathrm{~b}$ ) it is fully confirmed, with partial mediation found for the effect of the network dimension of technical quality (direct effect on overall quality is $\beta=$ $0.130, p<0.05$ ) and full mediation of the effect of the augmented technical quality dimension.

Table 1: Confirmatory factor analysis, correlations and discriminant validity

\begin{tabular}{|c|c|c|c|c|c|c|c|c|c|c|c|}
\hline$\#$ & Construct & Loadings & $C R$ & 1 & 2 & 3 & 4 & 5 & 6 & 7 & 8 \\
\hline 1 & FQ:Tangibles (4 items) & $0.56-0.72$ & 0.80 & 0.51 & 0.18 & 0.18 & 0.23 & 0.24 & 0.07 & 0.09 & 0.22 \\
\hline 2 & FQ: Reliability (5 items) & $0.63-0.81$ & 0.83 & 0.43 & 0.50 & 0.33 & 0.30 & 0.28 & 0.13 & 0.12 & 0.21 \\
\hline 3 & FQ: Responsiveness (4 items) & $0.65-0.92$ & 0.88 & 0.43 & 0.57 & 0.65 & 0.38 & 0.34 & 0.09 & 0.10 & 0.19 \\
\hline 4 & FQ: Assurance (4 items) & $0.72-0.86$ & 0.89 & 0.48 & 0.55 & 0.62 & 0.67 & 0.40 & 0.11 & 0.12 & 0.25 \\
\hline 5 & FQ: Empathy (5 items) & $0.62-0.81$ & 0.84 & 0.49 & 0.53 & 0.58 & 0.63 & 0.51 & 0.14 & 0.15 & 0.26 \\
\hline 6 & TQ: Network (6 items) & $0.67-0.82$ & 0.89 & 0.27 & 0.35 & 0.30 & 0.33 & 0.37 & 0.57 & 0.22 & 0.17 \\
\hline 7 & TQ: Augmented (5 items) & $0.72-0.86$ & 0.89 & 0.30 & 0.35 & 0.31 & 0.35 & 0.38 & 0.47 & 0.62 & 0.17 \\
\hline 8 & Corporate Image (5 items) & $0.67-0.90$ & 0.89 & 0.47 & 0.45 & 0.43 & 0.50 & 0.51 & 0.41 & 0.42 & 0.63 \\
\hline
\end{tabular}

Notes: $\mathrm{FQ}=$ functional quality; $\mathrm{TQ}=$ technical quality; $\mathrm{CR}=$ composite reliability; Average variances extracted are shown bold on the diagonal, correlations are below the diagonal and squared correlations above the diagonal; 
Table 2: Hypothesis test

\begin{tabular}{|c|c|c|c|}
\hline Relationships & $\begin{array}{c}\beta \\
(S . E .)\end{array}$ & $\mathrm{R} 2$ & Hypothesis test \\
\hline FQ: Tangibles $\rightarrow$ Corporate Image & $\begin{array}{c}0.478 * * * \\
(0.124)\end{array}$ & \multirow{7}{*}{0.69} & \multirow{4}{*}{$\mathrm{H} 1 \mathrm{a}$ - partially confirmed } \\
\hline FQ: Reliability $\rightarrow$ Corporate Image & $\begin{array}{l}0.034^{\text {ns }} \\
(0.123)\end{array}$ & & \\
\hline FQ: Responsiveness $\rightarrow$ Corporate Image & $\begin{array}{l}-0.075^{\mathrm{ns}} \\
(0.135)\end{array}$ & & \\
\hline FQ: Assurance $\rightarrow$ Corporate Image & $\begin{array}{l}0.247^{* *} \\
(0.161)\end{array}$ & & \\
\hline FQ: Empathy $\rightarrow$ Corporate Image & $\begin{array}{l}0.111^{\mathrm{ns}} \\
(0.201)\end{array}$ & & \multirow{3}{*}{ H1b - confirmed } \\
\hline TQ:Network $\rightarrow$ Corporate Image & $\begin{array}{c}0.272 * * * \\
(0.069)\end{array}$ & & \\
\hline TQ: Augmented $\rightarrow$ Corporate Image & $\begin{array}{l}0.102 * * \\
(0.053)\end{array}$ & & \\
\hline FQ: Tangibles $\rightarrow$ Overall quality & $\begin{array}{l}0.099 n s \\
(0.106)\end{array}$ & \multirow{8}{*}{0.85} & \\
\hline FQ: Reliability $\rightarrow$ Overall quality & $\begin{array}{l}0.046^{n s} \\
(0.103)\end{array}$ & & \\
\hline FQ: Responsiveness $\rightarrow$ Overall quality & $\begin{array}{l}0.110^{\text {ns }} \\
(0.113)\end{array}$ & & \\
\hline FQ: Assurance $\rightarrow$ Overall quality & $\begin{array}{l}-0.021^{\mathrm{ns}} \\
(0.135)\end{array}$ & & \\
\hline FQ: Empathy $\rightarrow$ Overall quality & $\begin{array}{l}-0.002^{\mathrm{ns}} \\
(0.167)\end{array}$ & & \\
\hline TQ: Network $\rightarrow$ Overall quality & $\begin{array}{l}0.130 * * * \\
(0.060)\end{array}$ & & \\
\hline TQ: Augmented $\rightarrow$ Overall quality & $\begin{array}{l}0.054^{\text {ns }} \\
(0.044)\end{array}$ & & \\
\hline Corporate Image $\rightarrow$ Overall quality & $\begin{array}{l}0.636 * * * \\
(0.067)\end{array}$ & & H2 - confirmed \\
\hline
\end{tabular}

Model fit: $\mathrm{df}=667 ; \times 2=1,777.506 ; \times 2 / \mathrm{df}=2.665 ; \mathrm{RMSEA}=0.066 ; \mathrm{NNFI}=0.977 ; \mathrm{CFI}=0.979 ; \mathrm{SRMR}=0.050$

Notes: B - unstandardized coefficient; S.E. - standard error; ${ }^{* *}-p<0.05,{ }^{* *}-p<0.001 ; N S-$ not significant; FQ $=$ functional quality; $\mathrm{TQ}=$ technical quality;

\section{DISCUSSION AND CONCLUSIONS}

Our study examined functional and technical service quality and their relations with perceived corporate image and overall quality assessment. The main contributions of the study are: (1) the definition, operationalization and empirical testing of a technical (output) quality dimension in mobile services as network (core) and augmented (additional) technical quality service dimensions, which extends earlier research discussion (e.g. Nimako et al. 2012; Kang and James 2004), and (2) the empirical testing of an adapted Grönroos model (1984), with a focus on the role of corporate image for the effects of perceived functional (SERVPERF) and the technical quality of services on overall service quality assessment.

The results of our analysis show that corporate image serves as a filter for the process of overall quality assessment, since none of the functional quality sub-dimensions has a direct effect on overall quality assessment, while the effect of two dimensions (tangibles and assurance) is fully mediated by image, which in line with the propositions of Grönroos (1984) and Andreassen and Lindestad (1998). On the other hand, technical quality has both a direct and indirect effect on overall quality assessment, with the network dimension strongly impacting both image and overall 
quality directly, while augmented technical elements impact overall quality only indirectly.

It is interesting to note that SERVPERF (Cronin and Taylor 1994), when analyzed through its sub-dimensions, is not fully efficient for explaining corporate image or overall quality evaluations. In their work, Kang and James (2004) have taken functional quality to be reflected through five SERVPERF dimensions, but did not analyze the role of each of the dimensions. We see now that the dimensionality of SERVPERF is important but not all dimensions contribute equally only two out of five matter in the context of mobile services. For mobile services that belong to the group of low-contact services functional quality might be less important (Mittal, 2016).

Furthermore, this fact underlines the importance of technical quality, which is supposed to have a stronger role for overall service quality perception. This finding points to the general importance of including technical quality perception (Kang 2006) in service quality analyses; without it, an important piece of the evaluation is missing and ignored. Finally, our empirical results further show that corporate image is partially a mediator for the effect of functional and technical quality perceptions on overall quality (Nguyen and LeBlanc 2001) and that this fact holds true in the example of a developing country.

When it comes to the managerial implications of this study, managers of telecommunication firms should note that the most important role for overall quality assessment is taken by the core service - the technical quality network dimension. It has both a direct and indirect effect on overall quality assessment. As previous research also shows (Kang 2006), this dimension has been usually disregarded by managers. Furthermore, it should be taken into account that the new dimension of technical quality - augmented technical quality - also plays a significant role for the assessment. Hence, managers in the mobile services industry, as well as managers of other low-contact services, should focus their efforts on improving core and augmented technical services, since they will result in shaping superior quality perception of customers. In terms of functional quality, tangibles and assurance should be taken seriously into account when developing a value proposition towards customers. Finally, telecommunication firms should acknowledge the role of corporate image, since it drives customer quality evaluations. Image seems to be particularly important for driving the functional quality assessment towards the overall quality assessment. Building corporate image should represent an imperative for these firms.

Our study is not without limitations. Namely, within the telecommunication services, the focus of the study was only on basic types of services, not on additional ones such as content diversity and quality, which will become increasingly significant for mobile Internet users. This study could be generalized at the level of mobile and telecommunication services, as well as at the level of low-contact and technology intensive services. However, further research should engage in operationalizing the technical quality dimension in different service industries so that more generalizable evidence of the process can be found.

\section{REFERENCES}

Aaker, D. A. 1996. Measuring brand equity across products and markets. California Management Review 38 (3): 102-120.

Anderson, J. C. and Gerbing, D. W. 1988. Structural equation modeling in practice: A review and recommended twostep approach. Psychological Bulletin 103 (3): 411-423.

Anderson, J. C. and Gerbing, D. W. 1991. Predicting the performance of measures in a confirmatory factor analysis with a pretest assessment of their substantive validities. Journal of Applied Psychology 76 (5): 732-740.

Andreassen, T. W. and Lindestad, B. 1998. Customer loyalty and complex services: The impact of corporate image on quality, customer satisfaction and loyalty for customers with varying degrees of service expertise. International Journal of Service Industry Management 9 (1): 7-23.

Angell, R. J., Heffernan, T. W. and Megicks, P. 2008. Service quality in postgraduate education. Quality Assurance in Education 16 (3): 236-254.

Arokiasamy, A. R. A. and Abdullah, A. G. 2013. Service quality and customer satisfaction in the cellular telecommunication service provider in Malaysia. Researchers World 4 (2): 1 .

Arora, R. and Stoner, C. 1996. The effect of perceived service quality and name familiarity on the service selection decision. Journal of Services Marketing 10 (1): 22-34.

Babakus, E. and Boller, G. W. 1992. An empirical assessment of the SERVQUAL scale Journal of Business Research 24: 253-268

Babic-Hodovic, V. 2010. Marketing usluga: koncept, strategije i implementacija. (Marketing Strategy: Concept, Strategy and Implementation). Sarajevo: Ekonomski fakultet.

Bagozzi, R. P. and Yi, Y. 2012. Specification, evaluation, and interpretation of structural equation models. Journal of the Academy of Marketing Science 40 (1): 8-34.

Ban, J. and Ramsaran, R. R. 2017. An Exploratory Examination of Service Quality Attributes in the Ecotourism Industry. Journal of Travel \& Tourism Marketing 34 (1): 132-148. 
Barich, H. and Kotler, P. 1991. A framework for marketing image management. Sloan Management Review 32 (2): 94-104.

Berry, L. L. 1986. Retail businesses are service businesses. Journal of Retailing 62: 3-6.

Bitner, M. J. 1991. The evolution of the services marketing mix and its relationship to service quality. In Service Quality: A Multidisciplinary and Multinational Perspective, edited by S. Brown, E. Gummesson, B. Edvardsson, B. and B. Gustavsson, 23-37. Lexington Books, New York, NY.

Blery, E., Batistatos, N., Papastratou, E., Perifanos, I., Remoundaki, G. andRetsina, M., 2009. Service quality and customer retention in mobile telephony. Journal of Targeting, Measurement and Analysis for Marketing 17 (1): 27-37.

Bowen, D. E. and Youngdahl, W. E. 1998. „Lean” service: in defense of a production line approach. International Journal of Service Industry Management 9 (3): 207-225.

Brady, K. M, and Cronin, J. J. Jr. 2001. Some New Thoughts on Conceptualizing Perceived Service Quality: A Hierarchical Approach. Journal of Marketing 65 (3): 34-49.

Brady, M. K., Cronin Jr, J. J., and Brand, R. R. 2002. Performanceonly measurement of service quality: a replication and extension. Journal of Business Research 55 (1): 17- 31.

Bravo, R., Montaner, T., and Pina, J. M. 2009. The role of bank image for customers versus non-customers. International Journal of Bank Marketing 27 (4): 315-334.

Brochado, A. 2009. Comparing alternative instruments to measure service quality in higher education. Quality Assurance in education 17 (2): 174-190.

Brown, S., Gummesson, E., Edvardsson, B. and Gustavsson, B. 2006. Service Quality: A Multidisciplinary and Multinational Perspective, Lexington Books, New York, NY.

Brown, T. J. and Kirmani, A. 1999. The influence of preencounter affect on satisfaction with an anxiety-provoking service encounter. Journal of Service Research 1 (4): 333-346.

Carman, J. M. 2000. Patient Perception of Service Quality: Combining the Dimensions. Journal of Service Marketing 14 (4): 337-352.

Cronin, J. J. and Taylor, A. S. 1992. Measuring Service Quality: A Reexamination and Extension. Journal of Marketing 56 (6): 55-68.

Dlačić, J., Arslanagić, M., Kadić-Maglajlić, S., Marković, S., and Raspor, S. 2014. Exploring perceived service quality, perceived value, and repurchase intention in higher education using structural equation modelling. Total Quality Management \& Business Excellence 25 (1-2): 141-157.

E.800. 1994. Terms \& Definitions related to quality of service (QoS) and network performance (NP) including dependability.

ETR 003 ed.2. 1994. Network Aspect (NA), General aspects of quality of service (QoS) and network performance (NP).
Finn, D. and Lamb, C. Jr. 1991. An Evaluation of the SERVQUAL Scales in a Retailing Setting. Advances in Consumer Research 18 (1): 483-490.

Firdaus, A. 2006. Measuring service quality in higher education: HEdPERF versus SERVPERF. Marketing Intelligence \& Planning 24 (1): 31-47.

Fombrun, C. J. 1996. Reputation: Realizing Value from the Corporate Image. Boston, Mass, Harvard Business School Press.

GSM Association: PRD IR.41. 2002. Identification of Quality of Service aspects of popular services (GSM and 3G), Version 3.1.0, April 2002.

Grönroos, C. 1982. Strategic Management and Marketing in the Service Sector. Helsingfors: Swedish School of Economics and Business Administration.

Grönroos, C. 1984. A Service Quality Model and Its Marketing Implications. European Journal of Marketing 18 (4): 36-40.

Grönroos, C. 1990. Service Management and Marketing: Managing the Moments in Truth in Service Competition, Lexington, MA: Lexington Books.

Gummesson, E. and Grönroos, C. 1988. Quality of services: lessons from the product sector. In Add Value to Your Service, edited by C. Surprenant, 186-190. American Marketing Association, Chicago, IL.

Hatch, M. J. and Schultz, M. 1997. Relations between organizational culture, identity and image. European Journal of Marketing 31 (5/6): 356-365.

Hatch, M. J. and Schultz, M. 2003. Bringing the corporation into corporate branding. European Journal of Marketing 37 (7/8): 1041-1064.

Hawabhay, B. B., Abratt, R. and Peters, M. 2009. The role of corporate communications in developing a corporate brand image and reputation in Mauritius. Corporate Reputation Review 12 (1): 3-20.

Hoffman, K. D. and Bateson, J. E. 2010. Services Marketing: Concepts, Strategies, \&Cases. Cengage Learning.

Huang, C. C., Yen, S. W., Liu, C. Y. and Huang, P. C. 2014. The relationship among corporate social responsibility, service quality, corporate image and purchase intention. International Journal of Organizational Innovation 6 (3): 68-84.

Jiang, J. J., Klein, G. and Crampton, S.M. 2000. A note on SERVQUAL reliability and validity in information system service quality measurement. Decision Sciences 31 (3): 725-744.

Johnson, C. W. and Sirikit, A. 2002. Service quality in the Thai telecommunication industry: a tool for achieving a sustainable competitive advantage. Management Decision 40 (7): 693-701.

Kahn, B.K., Strong, D.M. and Wang, R.Y. 2002. Information quality benchmarks: product and service performance. Communications of the ACM 45 (4): 184-192. 
Khan, A. M.2010. An Empirical Assessment of Service Quality of Cellular

Mobile Telephone Operators in Pakistan. Asian Social Science 6 (10):164-177.

Kang, G. and James, J. 2004. Service quality dimensions: an examination of Grönroos's service quality model. Managing Service Quality 14 (4): 266-277.

Kang, G. 2006. The hierarchical structure of service quality: integration of technical and functional quality. Managing Service Quality 16 (1): 37 - 50.

Kazoleas, D., Kim, Y. and Moffitt, M. A. 2001. Institutional image: a case study. Corporate Communications: an International Journal 6 (4): 205-216.

Keller, K.L. 1993. Conceptualizing, measuring, and managing customer-based brand equity. Journal of Marketing 57 (1): 1-22.

Khan, A. M., 2010. An Empirical Assessment of Service Quality of Cellular

Mobile Telephone Operators in Pakistan. Asian Social Science 6 (10): 164-177.

Kim, J. H. and Hyun, Y. J. 2011. A model to investigate the influence of marketing-mix efforts and corporate image on brand equity in the IT software sector. Industrial Marketing Management 40 (3): 424-438.

Kim, M. K, Park, M. C. and Jeong, D. H. 2004. The effects of customer satisfaction and switching barrier on customer loyalty in Korean mobile telecommunication services. Telecommunication Policy 28 (2): 145-159.

Lai, F., Griffin, M. and Babin, B. J. 2009. How quality, value, image, and satisfaction create loyalty at a Chinese telecom. Journal of Business Research 62 (10): 980-986.

LeBlanc, G. and Nguyen, N. 1996. Cues used by customers evaluating corporate image in service firms: An empirical study in financial institutions. International Journal of Service Industry Management 7 (2): 44-56.

Lehtinen, U. and Lehtinen, J. R. 1982. Service Quality: A Study of Quality Dimensions. Service Management Institute, Finland, Helsinki.

Lehtinen, J. R. 1983. Customer oriented service system. Service Management Institute, Finland, Helsinki.

Leisen B., and Vance C. 2001. Cross-National Assessment of Service Quality in the Telecommunication Industry: Evidence from the USA and Germany.Managing Service Quality 11 (5): 307-317.

Liang, D., Ma, Z. and Qi, L. 2013. Service quality and customer switching behavior in China's mobile phone service sector. Journal of Business Research 66 (8): 1161-1167.

Lim, H. J. 2005. A contingency approach to a customer loyalty model: An application to the mobile service context. Purdue University.

Lin, L.Y. and Lu, C.Y. 2010. The influence of corporate image, relationship marketing, and trust on purchase intention: the moderating effects of word-of-mouth. Tourism Review 65 (3): 16-34.
Lovelock, C. and Wirtz, J. 2011.Services Marketing: People, Technology, Strategy. Pearson Education.

Mackenzie, S. B., Podsakoff, P. M., and Podsakoff, N. P. 2011. Construct Measurment and Validation Procedures in MIS and Behavioral Research: Integrating New and Existing Techniques. MIS Quarterly 35 (2): 293-334.

Marković, S. 2006. Students' Expectations and Perceptions in Croatian Tourism and Hospitality Higher Education: SERVQUAL versus UNIQUAL. South East European Journal of Economics and Business 1 (1): 78-96.

Mittal, B. 2016. Retrospective: why do customers switch? The dynamics of satisfaction versus loyalty. Journal of Services Marketing 30 (6): 569-575.

Mohsin, A. and Lockyer, T. 2010. Customer perceptions of service quality in luxury hotels in New Delhi, India: an exploratory study. International Journal of Contemporary Hospitality Management 22 (2): 160-173.

Murgulets, L., Eklöf, J., Dukeov, I. and Selivanova, I. 2001. Customer satisfaction and retention in transition economies. Total Quality Management 12 (7-8): 1037-1046.

Nandan, S. 2005. An exploration of the brand identity-brand image linkage: A communications perspective. Journal of Brand Management 12 (4): 264-278.

Negi R. 2009. Determining Customer Satisfaction Through Perceived Service Quality: A Study Of Ethiopian Mobile Users. International Journal of Mobile Marketing 4 (1): 31-38.

Nguyen, N. and LeBlanc, G. 2001. Corporate image and corporate reputation in customers' retention decisions in services. Journal of Retailing and Consumer Services 8 (4): 227-236.

Nimako, G. S., Azumah, K. F., Donkor, F. and Adu-Brobbey, V. 2012. Confirmatory factor analysis of service quality dimensions within mobile telephony industry in Ghana. Electronic Journal Information System Evaluation 15 (2): 197-215.

Oliver, R. L. 1980. A cognitive model of the antecedents and consequences of satisfaction decisions. Journal of Marketing Research 4:460-69.

Oliver, R. L. 1997. Satisfaction: A Behavioral Perspective on the Consumer. New York: Irwin McGraw-Hill.

Opoku, R. A., Atuobi-Yiadom, N., Chong, C. S. and Abratt, R. 2009. The impact of internal marketing on the perception of service quality in retail banking: A Ghanaian case. Journal of Financial Services Marketing 13 (4): 317-329.

Özer, G. and Aydin, S. 2005. National customer satisfaction indices: an implementation in the Turkish mobile telephone market. Marketing Intelligence \& Planning 23 (5): 486-504.

Parasuraman, A., Zeithaml, V. and Berry, L. L. 1985. A Conceptual Model of Service Quality and Its Implications for Future Research. Journal of Marketing 49: 41-50.

Parasuraman, A., Zeithaml, V. and Berry, L. L. 1988. SERVQUAL: A Multiple-Item Scale for Measuring Consumer 
Perceptions of Service Quality. Journal of Retailing 64 (1): 12-40.

Parasuraman, A., Zeithaml, V. and Berry, L. L. 1991. Refinement and Reassessment of the SERVQUAL Scale. Journal of Retailing 67 (4): 420-450.

Parasuraman, A., Zeithaml, V. and Berry, L. L. 1994. Reassessment of Expectations as a Comparison Standard in Measuring Service Quality: Implications for Future Research. Journal of Marketing 58 (2): 201-230.

Ranaweera, C. and Neely, A. 2003. Some moderating effects on the service quality-customer retention link. International Journal of Operations \& Production Management 23 (2): 230-248.

Richard, M. D. and Allaway, A. W. 1993. Service quality attributes and choice behavior. Journal of Services Marketing 7 (1): 59-68.

Rust, R. T. and Oliver, L. R. 1994. Service Quality: Insights and Managerial Implications from the Frontier. In Service Quality: New Directions in Theory and Practice, edited by R. T. Rust and R. L. Oliver, 1-19. Thousand Oaks, CA: Sage.

Sandada, M. and Matibiri, B. 2016. An Investigation into the Impact of Service Quality, Frequent Flyer Programs and Safety Perception on Satisfaction and Customer Loyalty in the Airline Industry in Southern Africa. South East European Journal of Economics and Business 11 (1): 41-53.

Seth, A. and Gupta, M. K., 2008. Managing the Customer Perceived Service

Quality for Cellular Mobile Telephony: An Empirical Investigation. Vikalpa 33 (1): 19-34.

Shekarchizadeh, A., Rasli, A. and Hon-Tat, H. 2011. SERVQUAL in Malaysian universities: perspectives of international students. Business Process Management Journal 17 (1): 67-81.

Schneider, B. and Bowen, D. E. 1995. Winning the Service Game. Boston, Harvard Business School Press.

Sigala, M. 2006. Mass customization implementation models and customer value in mobile phones services: Preliminary findings from Greece. Managing Service Quality 16 (4): 395-420.

Solomon, M. R., Surprenant, C., Czepiel, J. A. and Gutman, E. G. 1985. A role theory perspective on dyadic interactions: the service encounter. Journal of Marketing 49: 99-111.

Souki, G. Q. and Filho, C. G. 2008. Perceived quality, satisfaction and customer loyalty: an empirical study in the mobile phones sector in Brazil. International Journal ofInternet and Enterprise Management 5 (4): 298 - 312.
Spreng, R. A. and Mackoy, R. D. 1996. An empirical examination of a model of perceived service quality and satisfaction. Journal of Retailing 72 (2): 201-214.

Spreng, R. A. and Page, T. J. 2003. A test of alternative measures of disconfirmation. Decision Sciences 34 (1): 31-62.

Sukumar, M. 2007. A study of consumer's preference and satisfaction towards various cell phone service providers (online). http://www.scribd. com/doc/13489869/ (accessed March 15, 2017).

Swartz, T. A. and Brown, S. W. 1989. Consumer and provider expectations and experiences in evaluating professional service quality. Journal of the Academy of Marketing Science 17 (2): 189-195.

Tiwari, P. and Verma, H. 2008. Service Quality in Telecom Industry: A Study of Telecom Service Providers in Dehradun City. NICE Journal of Business 3 (1/2): 77-86.

Van der Wal, R. W. E., Pampallis, A. and Bond, C. 2002. Service quality in a cellular telecommunications company: a South African experience. Managing Service Quality 12: 323-335.

Verma, R. and Young, T. S. 2000. Configuration of low-contact services. Journal of Operations Management, 18: 643-661.

Zeithaml, V., 1988. Consumer perceptions of price, quality, and value: a means-end model and synthesis of evidence. Journal of Marketing 52 (1): 2-22.

Zeithaml, V., Parasuraman, A. and Berry, L. L. 1990. Delivering quality service; Balancing customer perceptions and expectations. The Free Press, New York, NY.

Zeithaml, V., Berry, L. L. and Parasuraman, A. 1993. The nature and determinants of customer expectations of service. Journal of the Academy of Marketing Science 21: $1-12$.

Wang Y. and Lo, H-P. 2002. Service Quality, Customer Satisfaction and behavior intentions-Evidence from China's Telecommunication Industry. The Journal of Policy Regulation and Strategy for telecommunication Information and Media 4 (6): 50-60.

Ward, K. E. and Mullee, A. W. 1997. Quality of Service in Telecommunications. The Institution of Electrical Engineers Press, Stevenage.

Weiwei, T. 2007. Impact of corporate image and corporate reputation on customer loyalty: A review. Management Science and Engineering 1 (2): 57.

Woo, K. S. and Fock, H. K. Y. 1999. Customer satisfaction in the Hong Kong mobile phone industry. The Service Industries Journal 19 (3): 162-174. 